7. Frizzell RT, Lang GH, Lowance DC, Lathan SR. Hyponatremia and ultramarathon running. JAMA. 1986;255: $772-774$.

8. Ayus JC, Varon J, Arieff A.I. Hyponatremia, cerebral edema, and noncardiogenic pulmonary edema in marathon runners. Ann Intern Med. 2000;132:711-714.

9. Davis DP, Videen JS, Marino A, et al. Exercise-associated hyponatremia in marathon runners: a two year experience. $J$ Emerg Med. 2001;21:47-57.

10. Siegel AJ, Verbalis JG, Clement S, et al. Hyponatremia in marathon runners due to inappropriate arginine vasopressin secretion. Am J Med. 2007;120(461): e11-e17.

11. Noakes TD, Goodwin N, Rayner BL, Branken T, Taylor RK. Water intoxication: a possible complication during endurance exercise. Med Sci Sports Exerc. 1985;17: 370-375.

\section{Painful Sting After Exposure to Dendrocnide sp: Two Case Reports}

\section{To the Editor:}

The stinging trees, or Dendrocnide sp, are native plants from the rainforest area of northern Australia and Southeast Asia and belong to the Urticaceae family. When touched, these plants are known for inducing severe pain that can last for months. We describe in this letter 2 French tourists who came in contact with stinging trees in March 2012.

In the first case, a 49-year-old man without medical history vacationed to the Philippines on the island of Mindoro. While walking in the tropical rainforest, he happened to contact the stinging tree leaves (Dendrocnide sp). A few hours later, the volar region of both his hands became painful with a burning sensation, and he complained about paresthesia of the soles of his feet. He claimed he had not been in contact with cnidarians (marine organisms that eject nematocysts), which are another source of pruritus and painful reaction after skin exposure. Three weeks later, the subject still had moderate pruritus but no more burn injuries on his hand. However, paresthesia of both his feet continued. He was seen at the University Hospital Institute for Infectious and Tropical Diseases in Marseille.

In the second case, a 33-year-old man without medical history made contact with a Dendrocnide stem during his holidays in Vietnam. Within a few minutes, severe pruritus had developed on his ear and his arm. He quickly took a symptomatic treatment containing trolamine and acetaminophen. A family member contacted the Poison Control Center in Marseille where the doctor on duty advised him to disinfect the wounds and to continue the symptomatic treatment. Three days later, he observed a complete recovery of the burning wounds.

The Dendrocnide sp, or "stinging trees," belong to the Urticaceae family, like the European stinging nettle. There are about 37 species within the Dendrocnide genus: evergreen trees (for example, $D$ excelsa, $D$ photinophylla, D meyeniana) and shrubs (for example, $D$ moroides, $D$ cordifolia). The leaves are cordate, alternate, and covered with silicon/calcium-containing stinging hairs, as are the stems. Immature leaves are densely covered with stinging hairs, which become fewer in number on the surface of old leaves. ${ }^{1-3}$ They are often heavily chewed by insects, which gives a typical aspect to the leaves. The Dendrocnide sp fruits are aggregated, large, fleshy, and drupaceous and generally edible but some species (for example, $D$ excelsia) possess stinging

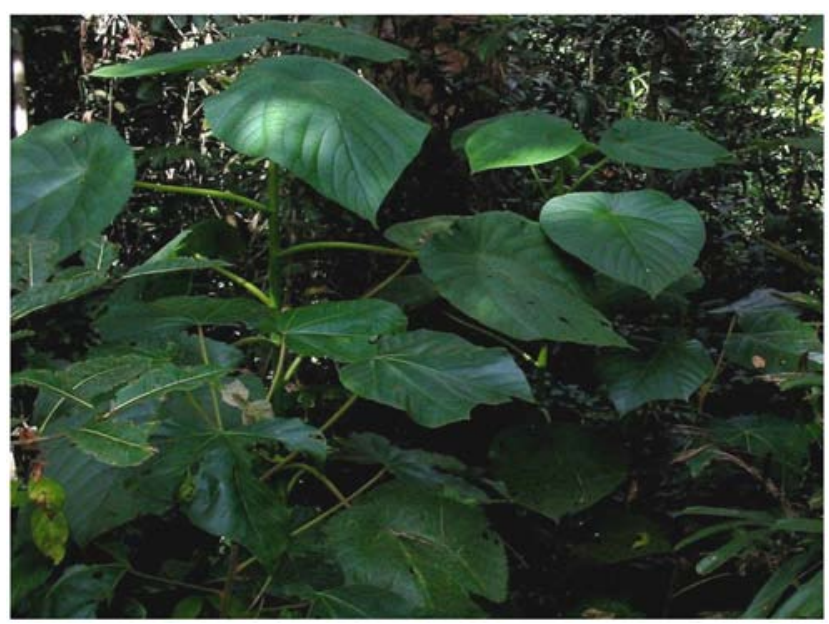

Figure 1. Dendrocnide moroides. 


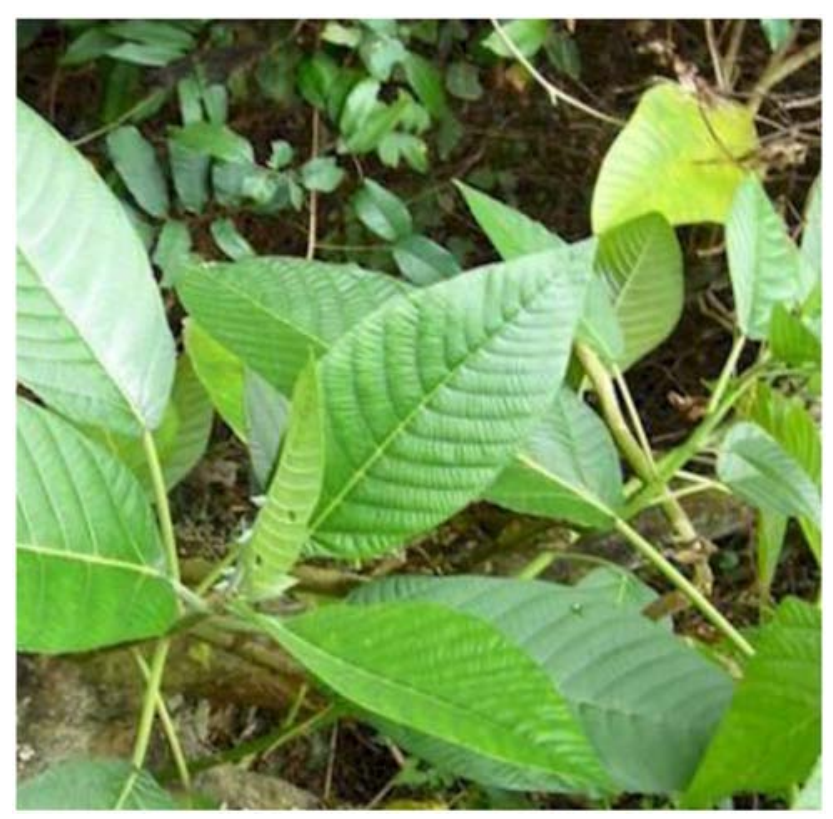

Figure 2. Dendrocnide meyeniana.

hairs on the fruits in addition to the stems and leaves to protect against fruit-eating animals. ${ }^{2,4}$

Stinging trees are common in Australia, where there are 6 species, which are especially found in the Queensland rainforest and particularly in areas disturbed by cyclones or by clearing. ${ }^{2}$ Moreover, the majority of publications about stinging trees comes from this country, certainly because the most painful of all the stinging trees, Dendrocnide moroides (or Laportea moroides), also called Gimpie-gimpie (Figure 1), grows in the Australian rainforest. ${ }^{5}$ However, Dendrocnide sp can also be found in other countries, especially in Southeast Asia.,

When a person touches Dendrocnide sp, its tips penetrate the skin, break off, and release irritant toxins. Its hairs are so tiny that the skin will often close over the hairs, making them difficult or impossible to remove. That can result in intense pain, piloerection, arteriolar dilation, and local sweating. ${ }^{6,7}$ The pain comes immediately after touching the plant, and then intensifies, reaching a peak after 20 to 30 minutes, and it can last for days or even months. Because the plants continuously shed their stinging hairs, pain may be referred to other areas of the body, and the air-borne stinging hairs can also trigger intense continuous bouts of sneezing. ${ }^{3,5}$

Severe cases have been reported in Australia: a man was found unconscious in 1955 some time after falling onto a stinging shrub. Deaths of horses and dogs have also been reported. The only human death was reported in 1922, after the sting of Laportea condata in New
Guinea. ${ }^{5,8}$ To remove the stinging hairs, some Australians use hair removal wax strips. But prevention is far better than cure; in Australian rainforest national parks, most tourist national walks stay clear of stinging trees. ${ }^{3,8}$ One toxin has already been identified in $D$ moroides and was named "moroidin." It is an octapeptide constructed exclusively from L-amino acids but it does not appear to be the only active component that can be extracted from this plant. ${ }^{5,9}$

Unfortunately, we do not know with which species of Dendrocnide our 2 patients came in contact. But the duration of the symptoms varied (more than 3 weeks in the first case and 3 days in the second), and therefore we infer that the species were different. However, the degree of contact with the stinging tree was probably not the same, leading to difficulty in identifying the exact species. It seems unlikely that the patients were in contact with $D$ moroides because it grows in other countries (Australia, Indonesia, and Moluccas), but the first case could have encountered $D$ meyeniana (Figure 2) or D stimulans, which grows in the Philippines. In the second case, the patient could have encountered $D$ urentissima, which is found in Vietnam.

Because more people are traveling the world, these unusual encounters are likely to occur among travelers who have never seen this kind of plant. Tourists who walk in the rainforest of certain countries should be aware of the existence of stinging trees and should be advised to wear pants and boots. Medical teams should also be informed about the symptoms of contact with 
stinging trees and be ready to manage this clinical picture when they see it.

\section{Acknowledgment}

We would like to express thanks to Carole Minois, PharmD, New South Wales, Australia, who provided help with language.

Corinne Schmitt, PharmD

Poison Control Center in Marseille, St Marguerite Hospital, Marseille, France

Philippe Parola, MD, PhD University Hospital, Institute for Infectious and Tropical Diseases, Marseille, France

Luc de Haro, MD, PhD Poison Control Center in Marseille, St Marguerite Hospital, Marseille, France

\section{References}

1. Hurley M. Growth dynamics and leaf quality of the stinging trees Dendrocnide moroides and Dendrocnide cordifolia (family Urticaceae) in Australian tropical rainforest: implications for herbivores. Aust J Botany. 2000;48:191-201.

2. Hawkeswood TJ. Observations on a Diphucephala species (Coleoptera: Scarabaeidae) and its feeding relationship with the giant stinging tree, Dendrocnide excelsa (Wedd.) Chew (Urticaceae) in Queensland, Australia. Entomologist. 1991; 110:170-177.

3. Queensland Poison Information Centre. Plants and mushrooms. Stinging trees. Available at: http://www.health.qld. gov.au/poisonsinformationcentre/plants_fungi/stinging trees.asp. Accessed 17 December 2012.

4. Chang YT, Shen JJ, Wong WR, Yen HR. Alternative therapy for autosensitization dermatitis. Chang Gung Med J. 2009;32:668-673.

5. Robertson PA, Macfarlane WV. Pain-producing substances from the stinging bush Laportea moroides. Aust J Exp Biol Med Sci. 1957;35:381-393.

6. Oelrichs PB, Roberson PA. Purification of pain-producing substances from Dendrocnide (Laportea) moroides. Toxicon. 1970;8:89-90.

7. Leung CTW, Williams DH, Barna JCJ, Foti S, Oelrichs PB. Structural studies on the peptide moroidin from Laportea moroides. Tetrahedron. 1986;42:3333.

8. Hurley M. Selective stingers. Ecos. 2000;105:18-23.

9. Kahn SD, Booth PM, Waltho JP, Williams DH. Computerassisted structure determination. Structure of the peptide moroidin from Laportea moroides. J Org Chem. 1989;54: 1901-1904.

\section{Wild Honey Intoxication in the Remote Himalaya}

\section{To the Editor:}

Wild honey (also known as mad honey) is believed in some communities to promote general well-being, including the treatment of gastric and coronary artery diseases, cold, and viral infection, as an analgesic, and as a sexual stimulant. During our voluntary work in the remote Himalaya in the Himalayan Rescue Association Manang Clinic (3500 m) in Nepal, we had an interesting case of a patient with wild honey intoxication. A 25year-old man, Nepali, without any history of disease and drug use was seen late afternoon at the aid post with symptoms of presyncope. The patient complained of significant weakness, alternating hot and cold sensations, tightness in the throat, and a "strange feeling" in the body. History taking revealed a normally fit and well person, with no relevant medical history and no recent ingestion of alcohol, medication, or recreational drugs. There was, however, a recent history of ingestion of freshly harvested wild honey. On his physical examination, the patient had marked bradycardia (heart rate 40 beats per minute, with occasional pulse oximetry heart rate recordings of as low as 35) and hypotension (blood pressure was $100 / 70 \mathrm{~mm} \mathrm{Hg}$, with intermittent readings of as low as $90 / 60 \mathrm{~mm} \mathrm{Hg}$ ). The patient was appreciably unwell, with symptoms of slow mentation, marked fatigue, and poor coordination. Pupils were equal and reactive, and neurologic examination was otherwise normal. The patient was treated with steroids and antihistamine and observed until he stabilized some hours later. He was discharged to his home under the care of his family. Unfortunately, owing to the remote nature of the aid post in which the patient was seen, sophisticated investigations such as serum analysis and electrocardiography were not available. In this case, without the benefit of real-time constant monitoring and laboratory investigation, such as has been described in previous reports of mad honey toxicity, we were limited to a diagnostic and management process the relied solely upon basic history taking, examination, and resuscitation techniques, which fortunately were, in this case, adequate and sufficient.

The main symptoms of the patient intoxicated by mad honey are dizziness, weakness, excessive perspiration, hypersalivation, paresthesias, cloudy vision, nausea, vomiting, syncope, salivation, hypotension, cardiac rhythm disturbance, and respiratory rate depression. Intoxication may lead to cardiac complications such as sinus bradycardia, sinus arrest, nodal rhythm, and varying degrees of atrioventricular block. ${ }^{1}$ No fatal case has been reported so far. ${ }^{1-3}$ Mad honey intoxication's symptoms are most likely dose-related. The exact dose 